\title{
Sedimentary record comparison of the Piwniczna and Poprad sandstones (Magura Unit, Outer Carpathians) - a study from the border area of eastern Slovakia and Poland
}

\author{
Diana DIRNEROVÁ ${ }^{1, *}$ and Roman FARKAŠOVSKÝ ${ }^{1}$ \\ 1 Technical University of Košice, Institute of Geosciences, Letná 9, 04200 Košice
}

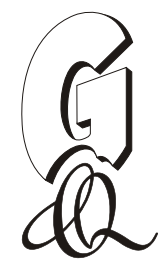
Dirnerová, D., Farkašovský, R., 2018. Sedimentary record comparison of the Piwniczna and Poprad sandstones (Magura
Unit, Outer Carpathians) - a study from the border area of eastern Slovakia and Poland. Geological Quarterly, 62 (4):
881-895, doi: $10.7306 / g q .1445$

Associate editor: Anna Wysocka

Thick deep-water sandstone successions are known from many localities in the Outer Western Carpathians. The present study is focused on comparison of deposits of the Piwniczna (PwSM) and Poprad (PpSM) Sandstone members belonging to the Magura Formation of the Magura Unit, outcropping in the eastern Slovakia and Poland border area. At the general level, a close similarity of the sandstone successions was confirmed by this study. However, in more detail, facies analysis shows differences in the thickness of the sandstone successions, in grain size and in the character of intervals between the thick sandstones. Thin-section study, though, showed almost the same modal composition in the sandstones analysed. The sandstone successions studied are interpreted as sandy debrites, the PwSM showing transitional facies to turbidites. These deposits represent channelized depositional lobes in the proximal part of a submarine fan with the PpSM closer to the source. The sediment source area was common to both lithostratigraphic units, and was most likely the South-Magura Ridge.

Key words: Outer Carpathians, Magura Unit, Piwniczna Sandstone Member, Poprad Sandstone Member, facies analysis, thin-section analysis.

\section{INTRODUCTION}

The sandstones known as the Piwniczna (PwSM) and Poprad (PpSM) Sandstone members, deposited in the Magura Basin during the Eocene, on which this study is focused, represent an important feature of the palaeodepositional history, demonstrating closure of the Outer Carpathian basins. These tectonic patterns related to the convergence between the ALCAPA microplate and the European Platform (e.g., Golonka et al., 2006) and led to the contemporary nappe structure of the Outer Carpathian Flysch Belt. As a result, from the north to the south are distinguished several nappes (Skole, Sub-Silesian, Silesian, Fore-Magura-Dukla and Magura Unit), which are all thrusted on top of each other, and together, over the Carpathian Foredeep. In the south, the Magura Unit is in tectonic contact with the Pieniny Klippen Belt (PKB, Fig. 1). The recent position of the uprooted nappes reflects the original configuration of the sedimentary basins, which were separated from each other,

\footnotetext{
* Corresponding author, e-mail: diana.dirnerova@tuke.sk
}

Received: August 24, 2017; accepted: July 31, 2018; first published online: December 20, 2018 and simultaneously supplied with sediment by "ridges". The most important source areas, considered in relation to the Magura Basin, were the Czorsztyn Ridge separating the Magura Basin from the PKB depositional area (Plašienka, 2003), South-Magura Ridge being active during the Early to Late Eocene to the south of the Magura Basin (Mišík et al., 1991) and the Silesian Ridge separating the Magura Basin from other flysch basins to the north (Ksiażkiewicz, 1960).

The sandstone successions studied were deposited in the southern part of the Magura Basin. Lithologically, they are regarded as very similar with differences only in the character of the mudstone intercalations (Oszczypko and Oszczypko-Clowes, 2010). Palaeogeographically, they are generally interpreted as turbidites representing distributary channels and lobes of the mid-parts of submarine fans (Oszczypko et al., 2005).

The provenance of Magura Unit rocks was studied mainly on the basis of exotic pebbles in conglomerates. All genetic types of rock are present (e.g., Nemčok et al., 1968; Oszczypko, 1975; Mišík et al., 1991; Oszczypko et al., 2006; Salata and Oszczypko, 2010). Exotic pebbles are represented by igneous rocks (volcanic rocks, rarely granitoids), metamorphic rocks (schists, gneisses, quartzites and cataclasites), sedimentary rocks (limestones, radiolarites) and vein quartz.

The source of conglomerate pebbles was probably the South-Magura Ridge and Czorsztyn Ridge that emerged during the Early to Late Eocene as part of an accretionary wedge 


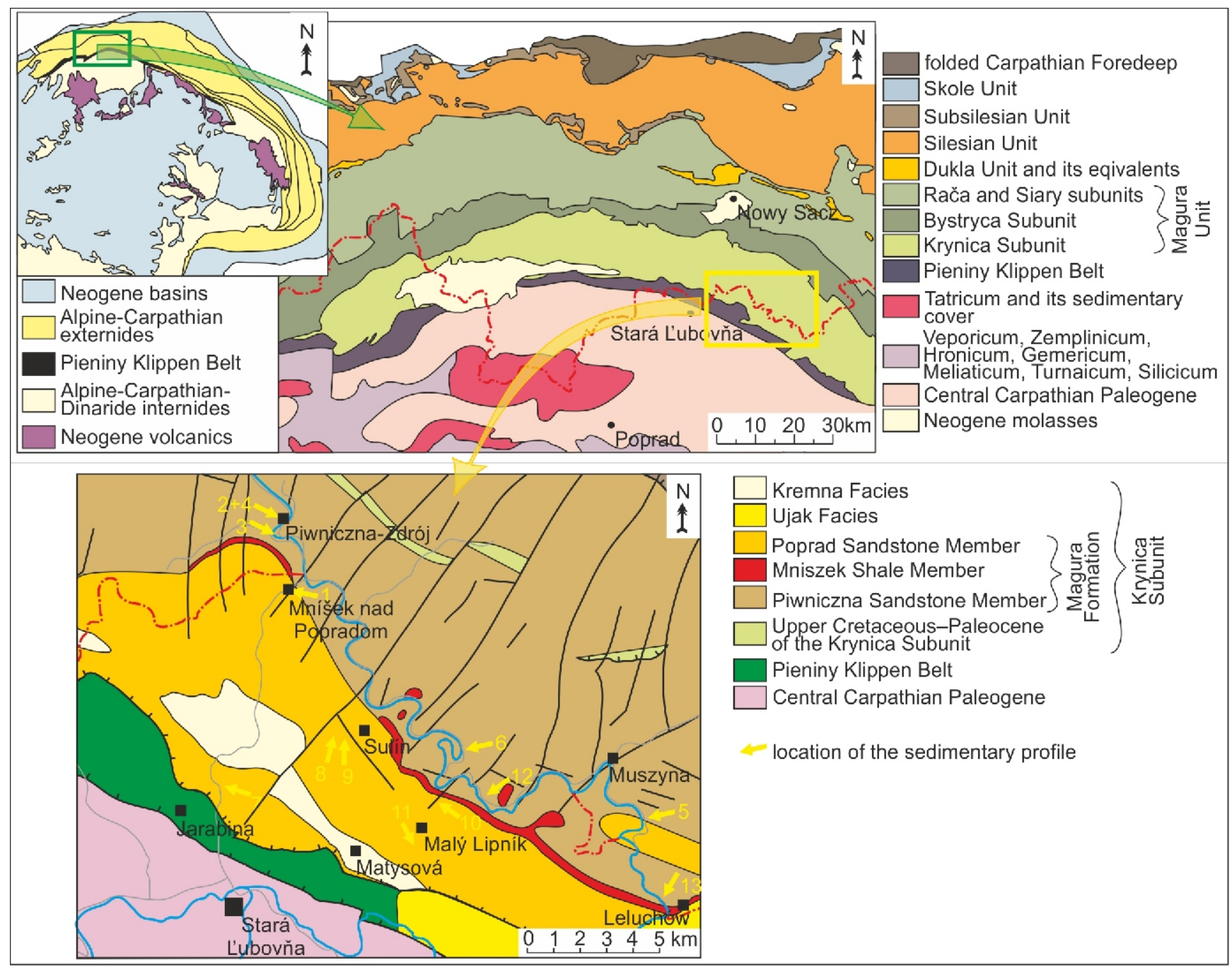

Fig. 1. Geological setting of the area studied (compiled by Nemčok, 1990; Kováč et al., 2003; Oszczypko et al., 2005; Oszczypko and Zuchiewicz, 2007; Plašienka and Mikuš, 2010)

(Mišík et al., 1991). The exotic rock clast provenance of the Krynica zone (Magura nappe) may be connected with Eocene exhumation of the Magura Basin basement or with crystalline material supplied from the Dacia and Tisza mega-units (Oszczypko et al., 2006; Salata and Oszczypko, 2010).

The heavy mineral composition of the Magura Basin sandstones shows that their southern source area was built of lowto medium-grade metamorphic rocks and igneous rocks associated with ophiolite sequences. The heavy mineral composition of the sandstones from the north-west indicates a source from low- to high-grade metamorphic rocks and granitoids (Oszczypko and Salata, 2005). Detrital chromian spinels from the Rača and Krynica subunits of the Magura nappe have an origin in mantle peridotites and in mid-ocean ridge basalts, back-arc basin basalts and sporadically in ocean-island basalts (Bónová et al., 2017).

This study analyses both the PwSM and PpSM to establish whether there are any lithological and/or petrographic differences between them, since they are defined as very similar and their interpretation is the same. At this stage of research, data from outcrops of both types of sandstone were collected and examined (Fig. 1).

\section{GEOLOGICAL SETTING OF THE STUDY AREA}

The study area is located in the vicinity of the Poprad River, near the state border between Slovakia and Poland, where deposits of the Magura Unit are preserved. The Magura Unit, as the innermost and largest of the Outer Carpathian group of nappes, comprises four nappes: the Siary, Rača, Bystrica and Krynica subunits, separated by thrust or reverse faults.

In this study, we analyse the sandstone successions of the Krynica Subunit exposed in road or creek sections between Piwniczna and Leluchów as well as near the villages of Malý Lipník, Sulín, Mníšek nad Popradom, and Jarabina (Fig. 1).

Stratigraphically, the Krynica Subunit of the Magura Unit consists of Cretaceous to Lower Miocene deposits (Birkenmajer and Oszczypko, 1989). The oldest rocks of Jurassic to Cretaceous age belong to the Grajcarek Group, which were deposited in the Magura Basin though subsequently they were incorporated into the PKB (Birkenmajer, 1977). Paleocene to Oligocene deposits in the study area are designated as the Beskid Group of the Krynica Subunit where, from the base to the top, the following formations can be designated (sensu Birkenmajer an Oszczypko, 1989; Nemčok et al., 1990; 


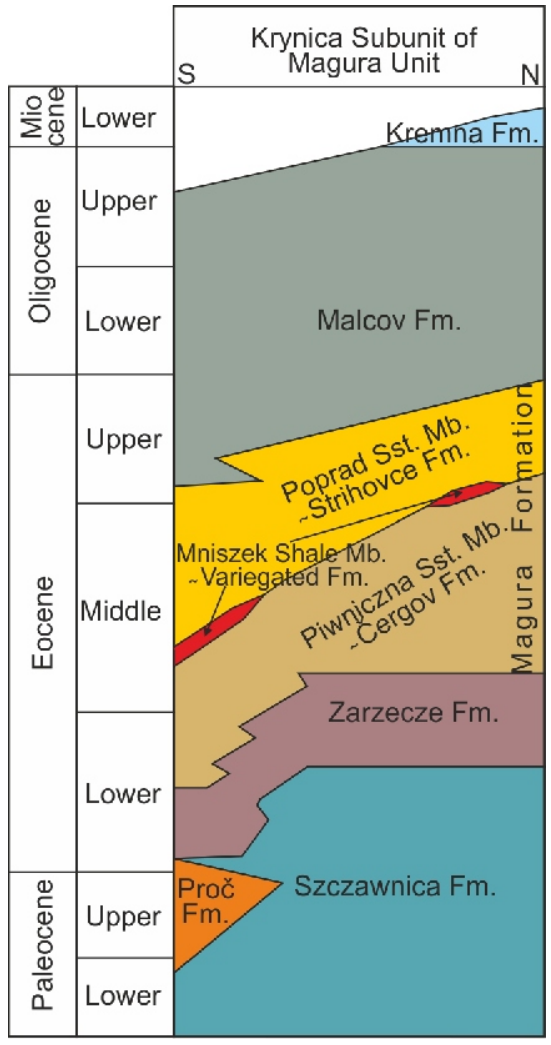

Fig. 2. Stratigraphy of the Krynica Subunit (compiled by Birkenmajer and Oszczypko, 1989; Kováčik et al., 2012)

Chrustek et al., 2005; Oszczypko et al., 2005; Žec et al., 2011; Kováčik et al., 2012; Fig. 2):

The Szczawnica Formation represented by finely rhythmic flysch with fine-grained, thin- to medium-bedded sandstones and slightly calcareous shales. A conglomerate-sandstone megabed, known as the Życzanów Member, occurs in the turbidite succession.

The Zarzecze Formation consists of fine- and very fine-grained sandstones alternating with marly shales, with a sandstone to shale ratio of 1:2 or 1:1 and locally with intercalations of Łacko type marls. Conglomerates, pebbly-mudstones and thick-bedded sandstones are locally also preserved and are defined as the Krynica Member.

The Frydman Formation is the transitional succession between the Szczawnica and Zarzecze formations evolved in the peri-Pieniny zone.

The Magura Formation is predominantly characterized by thick-bedded muscovite-rich sandstones with conglomerate and pebbly mudstone intercalations, which are designated as the PwSM and PpSM in Poland and as the Čergov and Strihovce formations in Slovakia. These lithostratigraphic units are separated from each other by the Mniszek Shale Member (Polish name) or Variegated Formation (Slovak name) defined by stripes and beds of red and green shales within thin- to medium-bedded sandstones with clay interclasts.

The Malcov Formation consists of thin- and medium-bedded muscovite-rich sandstones alternating with grey marly shales, with a sandstone to shale ratio of $1: 3$. The unit is locally represented also by marls of the Leluchów Marl Member, and the menilite-type shales of Smereczek Shale Member.

Kremna Formation is composed of thin- to medium-bedded turbidites with intercalations of thick sandstone beds and very thick dark grey marly shales.

\section{METHODS}

For the comparison of the two sandstone units, facies as well as thin-section analyses were used. The fieldwork in the area studied included detailed bed-by-bed logging of the preserved successions with focus on all sedimentary features such as lithology, geometry, sedimentary structures, bounding surfaces etc. (Figs. 3, 4 and 5). Sedimentary profiles were analysed by facies analysis, which suppose the definition of: (a) sedimentary facies based on their lithological attributes followed by their interpretation in terms of sedimentary processes; (b) facies associations based on genetic relation between the sedimentary facies followed by their interpretation in terms of ancient sedimentary environments.

Thin-sections of fine-grained sandstones from each profile were petrographically analysed using an Olympus $B X-53 \mathrm{mi}-$ croscope. A classification scheme based on the proportion of matrix, quartz, feldspar and lithic fragments (Pettijohn et al., 1972) was used to name and classify the sandstones studied. The Gazzi-Dickinson method of point counting was applied to evaluate the detrital composition of sandstones independent of grain size (Gazzi, 1966; Dickinson, 1970; Ingersoll, 1978; Ingersoll and Suczek, 1979; Ingersoll, et al., 1984). Point counting data from sandstones of the PwSM and PpSM were interpreted in QmFLt ternary provenance diagrams (Dickinson and Suczek, 1979; Dickinson, 1985; Dickinson, 1988) and potential sources of clasts were considered. Data obtained from both analyses were statistically evaluated and compared to establish any differences between the sandstone members studied.

\section{FACIES ANALYSIS}

General consideration of the sedimentary profiles recorded allow defininition of seven individual facies and three facies associations (Figs. 5 and 6).

The depositional environment of the sedimentary records analysed is generally interpreted as of deep-water type (e.g., Golonka et al., 2006). Considering that in this type of the environment, gravity flows represent the only way to transport large amounts of coarse-grained sediment into the depositional basin, which is subsequently deposited in the form termed a submarine fan, all of the following interpretations (both facies and facies associations) relate to such depositional conditions.

\section{FACIES}

Gravelly sandstones (Sgy) - A1.4 sensu Pickering et al. (1986), mGyS sensu Ghibaudo (1992)

This facies is represented by coarse- to very coarse-grained sandstones up to matrix-supported conglomeratic sandstones (Figs. 3A, 4A and 5A). The beds comprise subrounded clasts, which are granule-sized in the conglomerates. Clast imbrication or stratification was not observed. Most of the beds belonging to this facies are not very well-sorted though have no visible mudstone content. The thickness of these beds ranges from 10 up to $350 \mathrm{~cm}$. In case of the very thick beds amalgamation is recognizable. Bounding surfaces are sharp or scoured, although the scours are only flat ( $\max 15 \mathrm{~cm}$ deep; Fig. 4A).

Coarser grain size as well as massive structure indicate rapid en masse deposition by frictional freezing as the depositional process in this facies (e.g., Pickering et al., 1986; Kneller and Branney, 1995). Such abrupt deposition is most typical of high-density gravity flows as highly unsteady currents. 


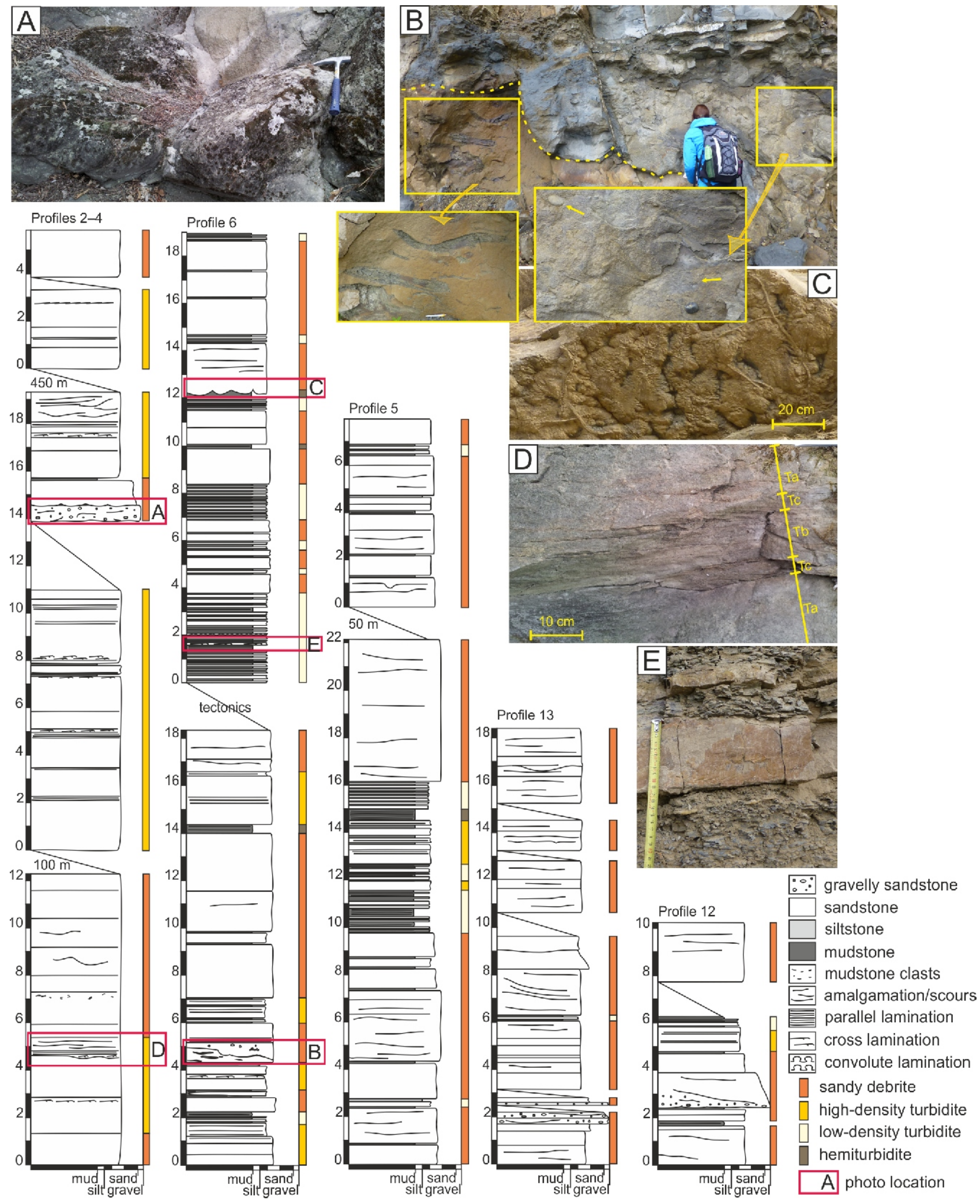

Fig. 3. Sedimentary profiles of the Piwniczna Sandstone Member and some features observed in the profiles

A - coarse-grained gravelly sandstone bed representing the Sgy facies; B - sandstone with elongated and deformed fragments of parallel-laminated mudstone interpreted as a slump structure, and bed with free-floating rounded clasts suspended in a sandy matrix, both sandstone beds represent a sandy debrite; $\mathbf{C}$ - load casts on the lower bounding surface of a sandstone bed as an indicator of rapid deposition, in addition, ichnofossils can be recognized on this surface; D - sandstone typical of a "reverse" Bouma sequence; E - parallel-laminated (fissile) mudstones alternating with sandstone beds interpreted as deposits of low-density currents 


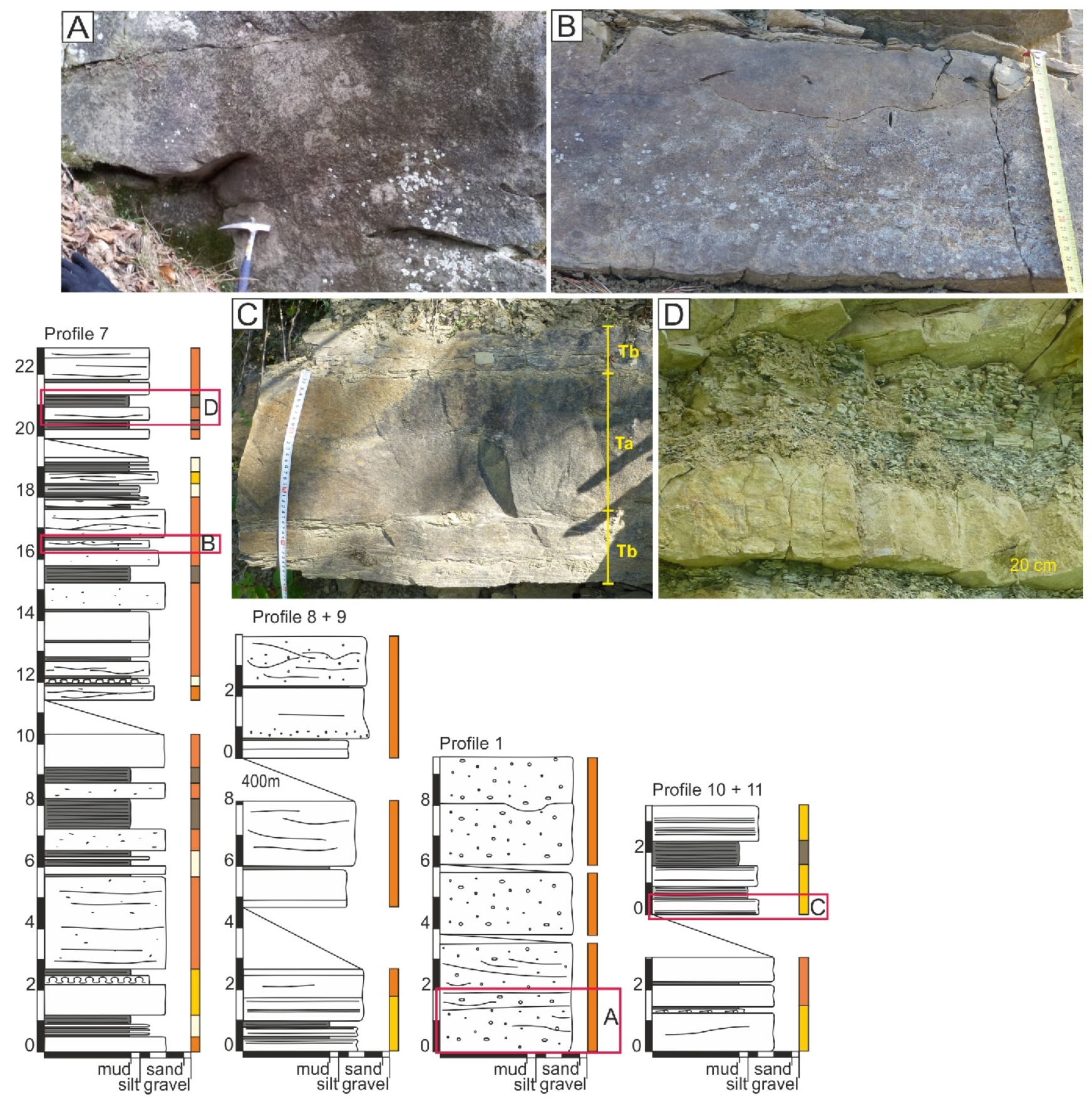

Fig. 4. Sedimentary profiles of the Poprad Sandstone Member and some features observed in the profiles

A - scours and channelized amalgamation surfaces in gravelly sandstones with no signs of gradation or intensive erosion; $\mathbf{B}$ - elongated mudstone clasts near the top of the bed, at the base sole structures can be seen; C - sandstone typical of a "reverse" Bouma sequence;

D - thick mudstone bed representing the Mpl facies; explanations as in Figure 3

Structureless sandstones $(\mathrm{Sm})$ - B1 sensu Pickering et al. (1986), mS sensu Ghibaudo (1992)

This is the most frequent facies in the successions studied. It is very variable in grain size as well as in thickness, comprising fine- to medium-grained sandstone beds, which are from 35 to $270 \mathrm{~cm}$ thick (B1.1 sensu Pickering et al., 1986; Fig. 5B). The very thick beds are mostly amalgamated. Although these sandstones are identified as a structureless, rare traces of normal grading are present. Beds are bounded by sharp, wavy or scoured surfaces, in several cases with preserved sole structures (Figs. 3C and 4B). Some of these beds contain mudstone clasts, which are small $(0.1-0.3 \mathrm{~cm}$ size in diameter), rounded and chaotically dispersed (Fig. 5C), or in some cases elongated $(1-3 \mathrm{~cm}$ ) with parallel long axes (Fig. 4B). Facies Sm includes also very thin to thin $(2-7 \mathrm{~cm})$ beds with sharp bases and no mudstone clasts. These are preserved heterolithic successions where they are developed as an isolated beds (Fig. 5J).

Structureless sandstones are interpreted as a Ta interval of the Bouma sequence (Bouma, 1962) or S3 interval of the Lowe sequence (Lowe, 1982). The deposition of the thick beds was most by gradual aggradation from quasi-steady depletive high-density turbidity currents, where grain interactions domi- 


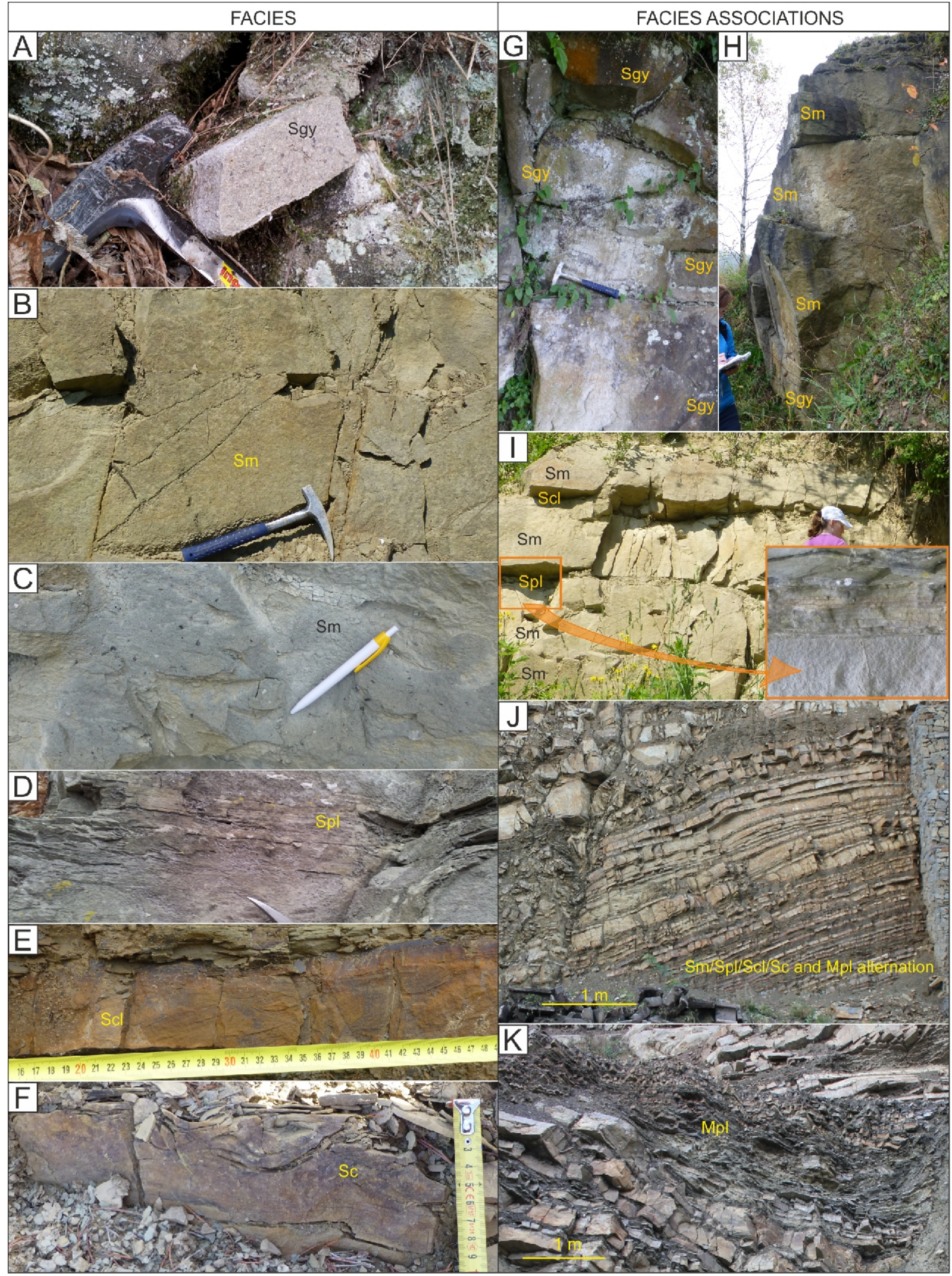

Fig. 5. Facies and facies associations defined in the study area

A - gravelly sandstone (Sgy); B - structureless sandstone (Sm); C - structureless sandstone with preserved mudstone clasts; D - parallel laminated sandstone (Spl); E - cross-laminated sandstone (Scl); F - convoluted sandstone (Sc); G, H - sandy debrites; I - high-density turbidites; J - low-density turbidites; $\mathbf{K}$ - hemipelagites consisting of the parallel-laminated mudstones (Mpl); for meaning of abbreviations see the text 
nate as a sediment support mechanism with hindered settling (Kneller and Branney, 1995). Occasional mudstone clasts can represent signs of inability of gravitational grain separation due to the high concentration of the gravity flow, which was too rapidly deposited.

\section{Slumped sandstone (Ss)}

This facies was recorded only in one sedimentary profile (profile 6, Fig. 3B). The sandstones are fine- to medium-grained, structureless and well-sorted. Individual beds reach $40-80 \mathrm{~cm}$ thick. The typical feature of these sandstones is that they contain many deformed elongated mudstone lenses up to intercalations (up to $50 \mathrm{~cm}$ long) as well as outsized rounded clasts (Fig. 3B). The beds typically have loaded bases.

The character of the sandstones is very similar to that of facies Sm. The only difference is in the mudstone content, signs of post-depositional deformation and/or slump structures and loaded bases. All of these features most likely resulted from fluidization or liquefaction, and therefore represent a secondary, not primary, structure. Accordingly, post-depositional slumping is suggested as responsible for the formation of this facies (Walker, 1976), which is therefore interpreted as a subfacies of the structureless sandstones.

Parallel-laminated sandstones (Spl)

This facies consists mainly of thin, only rarely of thick, parallel-laminated sandstone beds. The thickness of the beds commonly ranges from 2 to $35 \mathrm{~cm}$ and their bounding surfaces are sharp with no preserved sole structures (Fig. 5D, I). Signs of amalgamation were not recorded, and lamination is fine-scale. Medium-bedded sandstones are fine- to medium-grained. Within the sandstone successions analysed, they are incorporated in the massive structureless sandstones (in an upper, middle or lower position), locally with ripple-cross laminated parts (Figs. 3D and 4C). Very fine- to fine-grained sandstones, on the other hand, represent thin beds. These are preserved as interbedded with thin mudstone beds (Fig. 5J).

Parallel lamination in sandstone beds results from traction and fall-out deposition. This kind of deposition can occur under upper-stage flow regime, i.e. deposition under plane-bed condition ( $\mathrm{T}_{\mathrm{B}-2}$ sensu Talling et al., 2012), but also under the lower-stage flow regime, i.e. deposition by low amplitude bed-waves ( $T_{\mathrm{B}-1}$ sensu Talling et al., 2012). As a result, in the sedimentary profiles analysed, this facies is interpreted as of turbidite origin, high- as well as low-density. In the case of beds that are incorporated in the massive sandstones, the more likely depositional process is hindered settling typical of high-density turbidity currents. Each lamina results from rapid sediment fallout from overlying flow leading to formation of a near-bed layer with a sharp upper surface defined by relatively abrupt decrease in sediment concentration (Talling et al., 2012). Thin fine-grained sandstone beds interbedded with mudstones were deposited by more dilute flow, likely by fall-out deposition.

\section{Cross-laminated sandstones (Scl)}

This facies is not very frequent in the sedimentary successions analysed. Cross-lamination is typical of fine- to medium-grained sandstone beds with thicknesses between 6 and $24 \mathrm{~cm}$. Bounding surfaces are sharp or undulose. In all cases, the lamination was determined as of small scale as the thickness of individual forms does not exceed $3 \mathrm{~cm}$ (Fig. 5E). Within the sandstone successions, intervals of cross-lamination were recorded as following, or more rarely, as preceding parallel lamination (Fig. 3D). In addition, interbedding with thin mudstone beds was also distinguished in the sedimentary profiles analysed (Fig. 3E)

Formation of the cross-lamination relates to deposition in the lower-stage flow regime, i.e. occur under ripple conditions. Based on the preservation of this facies in association with the parallel laminated sandstone beds, a turbidite origin is most probable. The character of the preserved sequence (normal $\mathrm{Tb}-\mathrm{Tc}$ or "reverse" Tc-Tb) indicates the stage of the depositional turbidity current, where the normal sequence represents the waning discharge period, and the "reverse" sequence reflects the waxing discharge period. Preservation of the waxing discharge period is not common but it is possible in case of hyperpycnal flows (Mulder et al., 2003; Lamb et al., 2008).

\section{Convolute sandstones (Sc)}

Convolute sandstones are also not very common in the sedimentary profiles analysed. They are fine-grained and are deposited as thin to medium beds $(6-30 \mathrm{~cm})$ with sharp or undulose bedding surfaces (Fig. 5F).

This facies may be interpreted as a subfacies of both the parallel- and ripple cross-laminated sandstones because it forms by deformation of them. Consequently, convolute lamination in the studied deposits is interpreted as a secondary sedimentary structure formed shortly after deposition and before significant diagenesis due to fluidization or liquefaction of deposited sediment (Dżułyński, 1996). With respect to depositional processes in the primary sedimentary facies, convolute sandstones are interpreted as $\mathrm{Tb}$ and $\mathrm{Tc}$ divisions of the Bouma sequence.

Parallel-laminated mudstones (Mpl) - E2.2 sensu Pickering et al. (1986)

This facies consists of parallel-laminated (fissile) mudstones of light grey to dark grey colour (Figs. 3E, 4D and 5K). In some profiles, it is preserved as 40 to $100 \mathrm{~cm}$ thick intervals of more clayey non-graded beds incorporated into thick sandstone successions (Fig. 5K). There are also thin, siltier beds 2 to $10 \mathrm{~cm}$ thick with rare signs of grading. These are mostly preserved as rhythmic alternations with thin sandstone beds (Fig. 5J) or as caps on the thick sandstone successions. Lower as well as upper bounding surfaces of all mudstone beds are sharp. Signs of bioturbation or other secondary structures were not recorded.

As is indicated by the small grain size of the mudstones, their deposition relates to slow and gradual grain-by-grain or aggregate settling (Pickering et al., 1986). Simultaneously, parallel lamination in the mudstones implies continuous sediment accumulation as a single depositional event (Lazar et al., 2015; $\mathrm{T}_{\mathrm{E}-1}$ sensu Talling et al., 2012). Regarding the association of this facies with the sandstone successions, such sedimentation can occur as the last stage of gravity flow deposition, the resulting deposits being interpreted as the Te division of the Bouma sequence. This is the most probable depositional process in the case of the thin to medium beds. On the other hand, parallel laminated mudstones can also represent a calm stage of deep-water deposition during which hemipelagites to pelagites form, but these deposits are typically intensely bioturbated. A transitional depositional process, known as hemiturbiditic sedimentation (Stow and Wetzel, 1990) is also possible, by which medium to thick successions of this facies have formed.

\section{FACIES ASSOCIATIONS}

\section{Sandy debrites}

The association is characterized by very high, $84-100 \%$ ( $98 \%$ on average) sandstone content and all of these sandstones are structureless. Regarding the defined facies, it consists of structureless sandstones (Sm), occasionally with a preserved thin layer of gravelly sandstone (Sgy) at the base, and locally capped by thin beds of parallel laminated mudstones (Mpl; Figs. $5 \mathrm{H}$ and $6 \mathrm{~A}$ ). In one of the sedimentary profiles studied, only gravelly sandstones were preserved (profile 1; 
Figs. 4A and 5G). The thickness of this facial association ranges 0.5 to $3 \mathrm{~m}$. Structureless sandstones, which represent the main facies in this association, can be with or without mudstone clasts and these can be preferably oriented or chaotically dispersed (Figs. $4 \mathrm{~B}$ and 5C). In one case, the structureless sandstone beds are replaced by slumped sandstones (Ss), most likely as a result of post-depositional deformation (Fig. 3B)

The thickness, grain size as well as the structureless character of preserved deposits of this facies association indicate relatively rapid deposition from high-density gravity flows, where suspension-load fallout rate was sufficiently high to suppress bedload development and traction transport (Lowe, 1982; Arnott and Hand, 1989). Chaotically scattered mudstone clasts also support the inference that the gravity flow was too concentrated and too rapidly deposited to allow grain-size separation (as recorded in normal grading or a Bouma sequence).

As a high-density gravity flow, we may consider a debris flow (Dcs sensu Talling et al., 2012) as well as a high-density turbidity current, since the both of these are able to deposit the sediments described in this association. However, once the theory of the transformation of the gravity flows from high- to low-density (e.g., Hampton, 1972) is taken into account, we assume that these sandstone successions represent transitional deposits between debrites and high-density turbidites. This could be the reason why the signs of both kinds of flow are recorded. Consequently, the association is interpreted as deposits of lower part of high-density turbidity currents, i.e. grain flows (sensu Lowe, 1979) or sandy debris flows (Shanmugam, 2013), and is defined as comprising sandy debrites.

High-density gravity flows forming this association may be an indicator of proximity to the source area, where mainly channel-fill sequences should be deposited (Mutti, 1987). These se- quences are characterized by coarse-grained and scoured facies as well as the fining-upwards cycles (Mutti, 1987). However, occasionally preserved scours and gravelly sandstone beds (Figs. 4A and $5 \mathrm{G}$ ) typical of this association are not sufficient developed; scours are too shallow and Sgy facies are an exception rather than a rule. Consequently, a more probable interpretation is as a depositional lobe, where the high sandstone net to gross ratio and exclusively structureless character of the beds indicate deposition in a lobe apex to axis area (sensu Prèlat et al., 2009; Spychala et al., 2017).

High-density turbidites

The second association defined is similar to the previous one but with no mudstone clasts and with a higher incidence of sedimentary structures. The sandstone to mudstone ratio is high since $75-100 \%$ (92\% in average) of the association thickness consists of sandstones. Structureless sandstone beds $(\mathrm{Sm})$ are still predominant and are the beds of the greatest thickness. They represent up to $80.5 \%$ of all sandstone beds. They gradually pass into parallel laminated (Spl) and/or cross-laminated sandstones (Scl; Fig. 5l). Occasionally, thin layers of parallel laminated mudstone (Mpl) cap the sedimentary succession (Fig. 6A). Rarely, convoluted sandstone beds can be recognized, which most likely relates to dewatering of the deposited sediment (Butler et al., 2016). The thickness of the association reaches $1-2 \mathrm{~m}$ on average, although in one profile it is up to $11 \mathrm{~m}$ (profile 3 , Fig. 3).

The increased incidence of sedimentary structures indicates that initially fully concentrated gravity flow was transformed to bipartite flow with grain flow in the lower part (structureless beds formed) and a turbidity current in the upper part (structured beds formed). Such internal differentiation within one gravity flow is typical for high-density turbidity currents (e.g., Lowe, 1979). The upper part of the flow is more di-

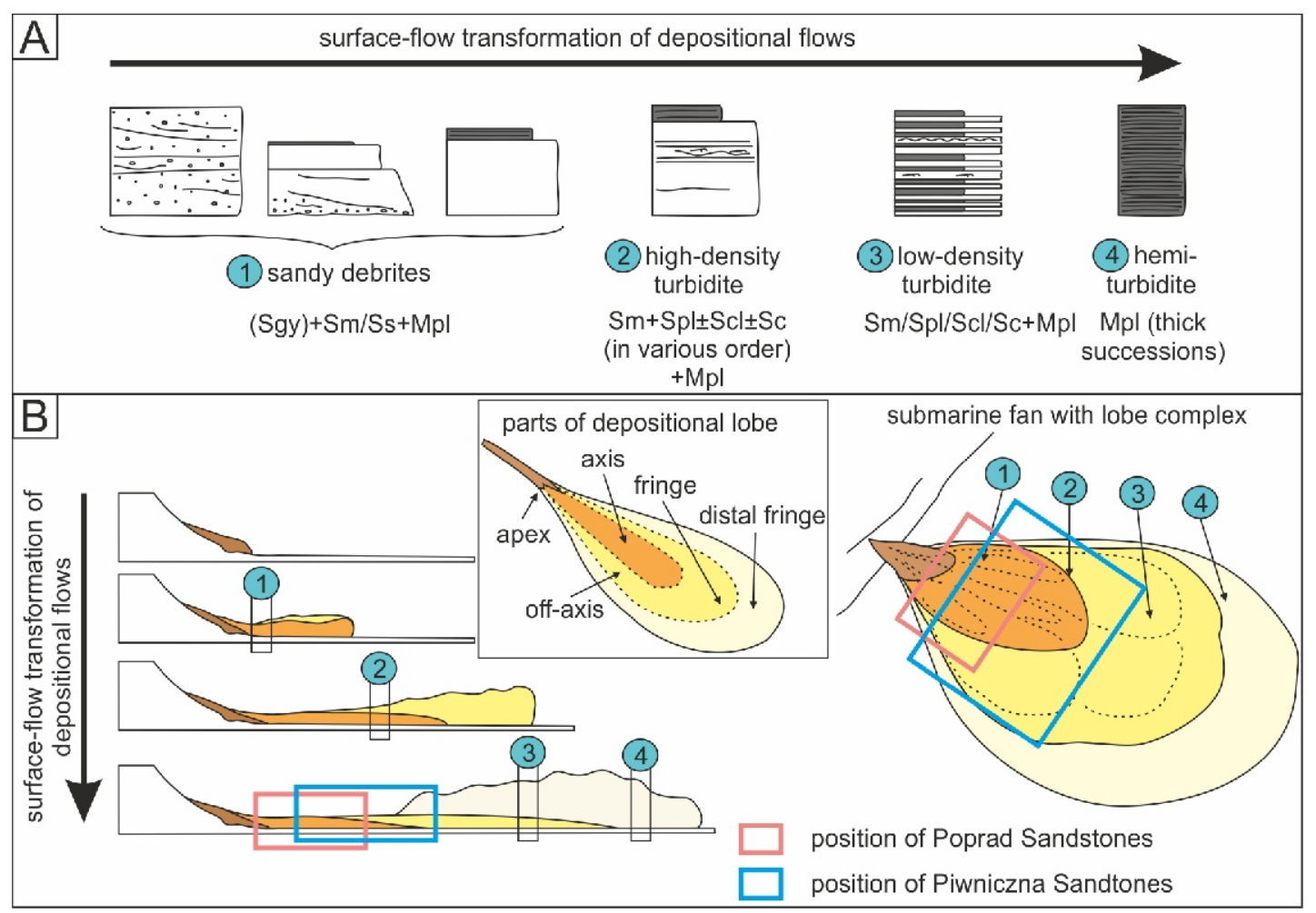

Fig. 6. Facies associations of the sedimentary profiles analysed (A) and their interpretation (B) in relation to depositional process as well as depositional environment 
lute and turbulence becomes a dominant sediment support mechanism. In such depositional conditions, formation of tractional structures is enhanced. Hence, the association described is interpreted as deposits of high-density turbidity currents as a whole (not only the lower part as in the case of the previous association), i.e. high-density turbidites. Compared to "classical" turbidites (Bouma, 1962; Lowe, 1982), these differ in the pattern of typical Bouma sequence divisions. Successions in which such "reverse" sequences (Figs. 3D and 4C) are preserved most likely represent the waxing - waning phases of a hyperpycnal turbidity current (Mulder et al., 2003).

As regards the depositional environment, as with the first association, this one is also interpreted as representing a depositional lobe, although a more distal - lobe-off axis position (sensu Prèlat et al., 2009; Spychala et al., 2017) is suggested. The more distal position is indicated by the lower sandstone to mudstone ratio as well as the lower structureless to structured sandstone ratio, i.e. deposition by less concentrated depositional flow.

\section{Low-density turbidites}

The main sign of this association is that the sandstone to mudstone ratio is more equal, as the sandstones are very thin to thin, and only in a few cases are medium-bedded in this association (Fig. 5J). Recorded sandstone beds are massive (Sm), parallel- (Spl) to cross-laminated (Scl) or convolute (Sc), and they alternate with thin beds of parallel-laminated mudstones (Mpl). Consequently, the association can be described as comprising thin-bedded sandstone-mudstone couplets (C2.3 sensu Pickering et al., 1986; IMS sensu Ghibaudo, 1992). The thickness of this association ranges from 30 to $180 \mathrm{~cm}$.

The gravity flows that formed this association are interpreted as low-density turbidity currents, i.e. flows of very low concentration and of fully turbulent flow regime (surge-like turbidity flow sensu Mulder and Alexander, 2001). The preservation only of the upper part of the ideal Bouma sequence indicates that sediments of this association were deposited from the upper part of the initially bipartite high-density turbidity current (of the previous association) during the final stage of its depositional activity. Sedimentary particles in such a gravity flow are maintained in suspension due to the upwards component of turbulence and their settling is slow, with some traction, producing sedimentary structures and bedforms of typical Bouma Tb-Td divisions (Mulder and Alexander, 2001).

Based on the sedimentary character of this association, a possible interpretation as the fringes of depositional lobes (sensu Prèlat et al., 2009; Spychala et al., 2017) as well as channel-related overbank deposits (sensu Mutti, 1987). Regarding the interpretation of the previous associations and their interconnection to this one, the most probable depositional environment relates to a lobe structure. Hence, in this study, low-density turbidites are defined as the fringing parts of the depositional lobe to interlobe areas in the lobe structure.

\section{THIN-SECTION ANALYSIS}

\section{PIWNICZNA SANDSTONE MEMBER}

Based on thin-section analysis, sandstones are classified as feldspathic, sub-feldspathic and lithic arenites as shown by their modal composition. They contain $64-89 \%$ clastic material, 5-10\% matrix and $2-31 \%$ cement. Clastic material consists mainly of quartz, feldspar and different kinds of rock fragments. Unstable feldspar and lithic carbonate fragments represent a substantial part of the rocks indicating mineralogical immaturity of the samples analysed. Texturally, they are identified as im- mature to submature, moderately to poorly sorted sandstones. The average grain size indicates very fine to fine sands, consisting mostly of angular to subangular shaped grains, but there are also larger (up to $750 \mu \mathrm{m}$ ) more rounded grains represented mainly by feldspars, limestones and metamorphic rock fragments.

Quartz grains represent 33-55\% of sandstones' volume and mostly are represented by monocrystalline non-undulatory grains (Figs. 7B, C and 9). These indicate mainly magmatic sources of fragments, but in the case of the very fine to fine sandstones, the grains may have originated also by disintegration of originally larger polycrystalline grains of metamorphic rocks. Gradual reduction of detritus grain size can lead to decrease in polycrystalline and undulatory quartz grain content in the sandstone. The feldspars form 9-19\% of the sandstones' volume. Alkali feldspars predominate over plagioclases, most likely because of their higher resistance to chemical weathering. Microcline fragments and perthitic feldspar grains are common, many being markedly altered to fine-grained aggregates of white mica or clay minerals (Fig. 7E, F). Spme feldspars commonly include cloudy or brown-coloured parts. Sources of the feldspars were probably granitic and gneissic rocks. Less frequent grains are represented mainly by mica and opaque minerals. Muscovite is more common than biotite, most likely due to higher weathering resistance. A very rarely identified component was glauconite, a mineral formed exclusively in marine sediments in synsedimentary to diagenetic processes. Lithic fragments represent $10-17 \%$ of sandstone volume and they consist of carbonate rocks (excepting the samples from profile 5), phylites, mica schists, granitic rocks and occasionally also of sedimentary cherts. The matrix is formed of aggregates of clay minerals, white mica and quartz. Chlorite and iron oxides are preserved in lesser amounts. The cement is composed of calcite that in most cases infills pores. Higher content of the calcite cement was identified in some parts of samples from profile 6 .

\section{POPRAD SANDSTONE MEMBER}

From the modal composition, the Poprad Sandstones are classified as sub-feldspathic and lithic arenites (Fig. 9), in one case as a calclithite (profile 7) as a result of the substantial content of carbonate rock fragments. Clastic material in the samples studied represents $72-91 \%$, matrix $5-14 \%$ and cement $4-14 \%$. The most common clastic component is quartz but the content of unstable feldspar and limestone grains is also significant. Therefore, the sandstones are defined as mineralogically immature. Based on the average grain size, samples can be interpreted as a very fine- to fine-grained or in some samples up to medium-grained sandstones (profile 7 ). The grains are subangular to subrounded in most cases, although some less stable larger fragments may be of subrounded to rounded shape. Based on matrix content, sorting and roundness of individual grains, the sandstones can be considered as texturally immature.

The amount of quartz grains (Fig. 7B-D) in the sandstones, mostly represented by monocrystalline undulatory grains, is $35-52 \%$ (Fig. 9). Feldspar grains constitute $7-18 \%$ of sandstone volume and include alkali feldspars as well as plagioclases (Fig. 7G, H). Alkali feldspars, consisting mainly of orthoclase and rarely microcline, are more abundant. Frequently, the feldspar grains are replaced by white micas and clay minerals. The lithic fragments form $6-40 \%$ of the sandstone volume. They are represented by all rock types in the samples studied (Fig. 8A-D). Lithoclasts of phyllites, mica schists, limestones (dominant only in profile 7 comprising up to $82 \%$ of lithic fragments) and sporadically also larger grains of 

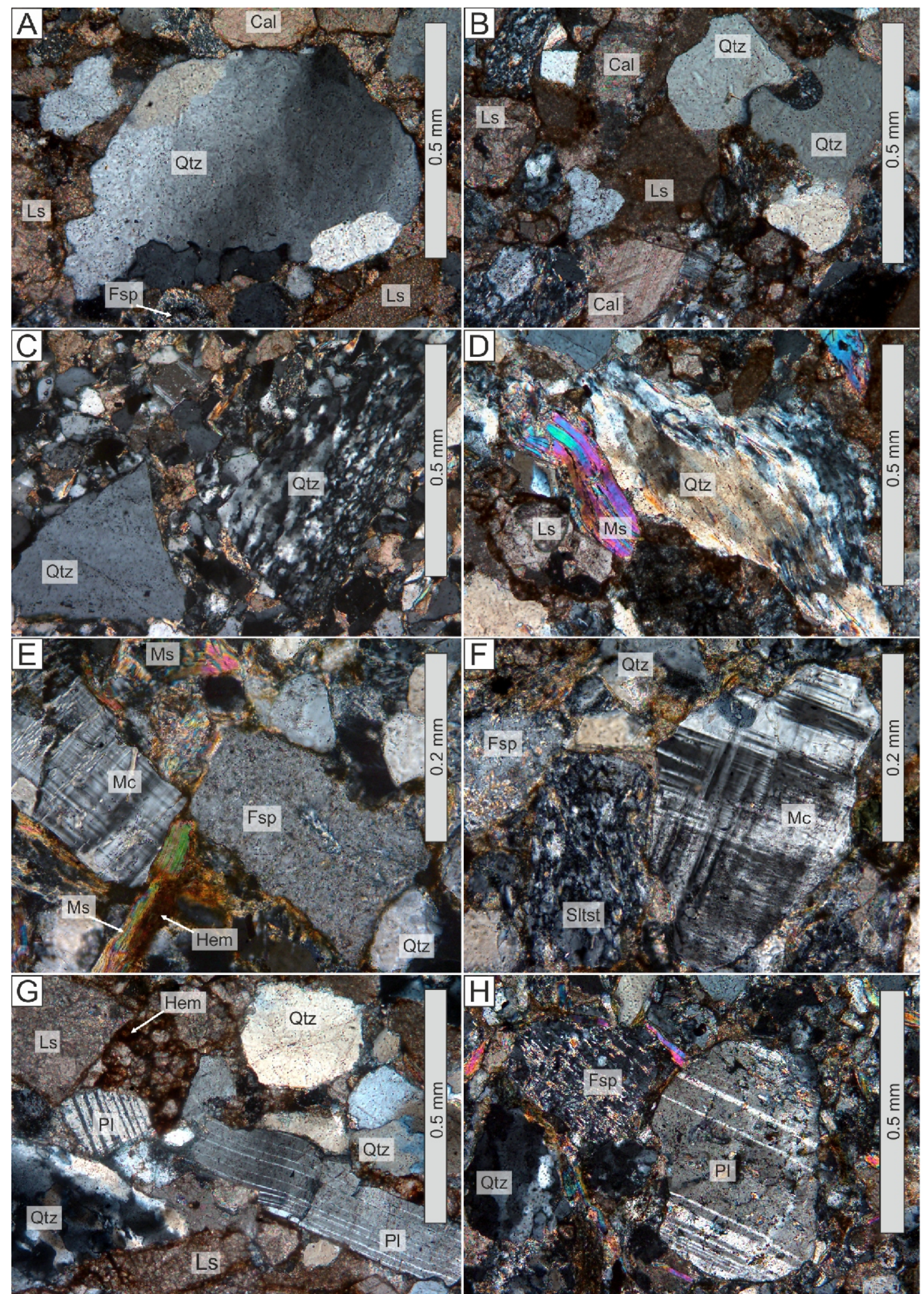

Fig. 7. Quartz and feldspars as common grains in both Piwniczna and Poprad sandstones

A - subrounded polycrystalline quartz grain of metamorphic origin with visible undulose extinction in the central part and subgrains near the margin (profile 5); B - monocrystalline quartz grains originally representing phenocrysts of volcanic rock, in which corrosion features due to remelting are visible (profile 7); $\mathbf{C}$ - angular monocrystalline quartz of magmatic origin (left) and polycrystalline quartz of metamorphic origin (right) with typical fabric indicating dynamic recrystallization and with shape-preferred orientation defining foliation (profile 8); D - subangular polycrystalline quartz of metamorphic origin, in which subgrains show signs of shape-preferred orientation and ductile deformation (profile 7); E - angular grains of microcline and slightly altered orthoclase as the most common alkali feldspars (profile 5); $\mathbf{F}$ - subangular microcline with typical cross-hatched twinning (right) and hydrothermally altered sericitized feldspar (profile 2); G subrounded plagioclase with typical polysynthetic twinning (profile 7); $\mathbf{H}$ - rounded plagioclase with visible polysynthetic twinning and feldspar with visible aggregates of white mica (profile 9); crossed polarized light; Cal - calcite, Fsp - feldspar, Hem - hematite, Ls - limestone, Mc - microcline, Ms - muscovite, PI - plagioclase, Qtz - quartz, Sltst - siltstone 

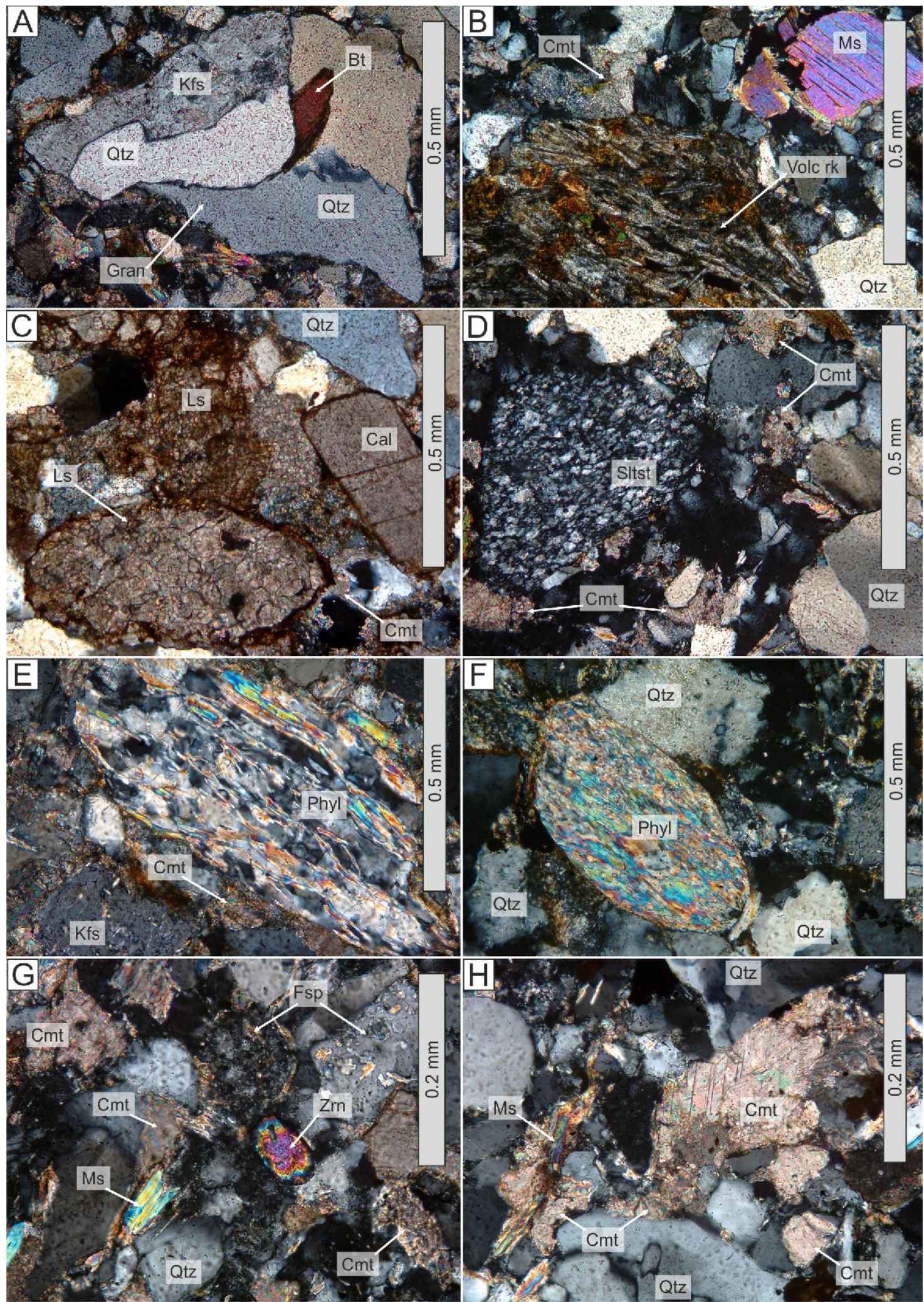

Fig. 8. Different types of rock and mineral fragments in the Piwniczna and Poprad sandstones

A - fragment of plutonic granitic rock composed of quartz, feldspar and biotite (profile 9); B - rare fragment of basic volcanic rock with planar fabric composed mainly of plagioclase, dark and opaque minerals, in the upper right part of the photomicrograph are clastic grains of white mica (profile 10); C - fragments of sedimentary carbonate rocks are formed mainly by limestones, grains of calcite being present only occasionally (profile 7); $\mathbf{D}$ - fragments of siliciclastic argillaceous sedimentary rocks and silicate siltstones are relatively common (profile 10); $\mathbf{E}$ - the most abundant metamorphic rock fragments are phyllites, they are composed mainly of oriented quartz and white mica grains (profile 4); $\mathbf{F}-$ rounded clast of phyllite formed by white mica with typical foliated fabric (profile 5); $\mathbf{G}$ - rare grains of zircon were constituents of granitic rocks originally (profile 8 ); $\mathbf{H}$ - aggregate of calcite cement with typical cleavage planes among the clastic fragments (profile 9); crossed polarized light; Bt - biotite, Cmt - cement, Gran - granite, Kfs - K-feldspar, Phyl - phyllite, Volc $\mathrm{Rk}$ - volcanic rock, other explanations as in Figure 7 
granitic rocks were recognized. The sample matrix consists of aggregates of fine-grained quartz, feldspar and mica minerals. Clay minerals can be distinguished in some parts too. The cement is mostly formed of calcite (Fig. $8 \mathrm{H}$ ) that infills space between the grains. Detrital grains in sandstones from profile 7 are typified by a thin brown iron oxide coating.

\section{SOURCE ROCKS}

Considering the similarities between both types of sandstone analysed, they are interpreted as originating from material of the same petrographically diverse source area. Most of the sandstones studied represent petrofacies that plot near the centre of the QmFLt diagram (Fig. 9). This region of mixed provenance is not typical of any generic provenance type. Petrofacies of mixed provenance could be derived from suture belts or collision orogens where contrasting source terranes have been placed into close proximity (Dickinson, 1988).

The sandstones studied contain fragments of plutonic granitic rocks (Fig. 8A) and basic volcanic rocks (Fig. 8B) only rarely. However, substantial amounts of the quartz, feldspar and mica grains are originally from granitoid rocks. Although acid volcanic rocks were not recorded, non-undulatory quartz grains with signs of magmatic corrosion with idiomorphic shape (Fig. 5B) indicate the volcanic origin of some grains. Metamorphic rocks represented mainly by fragments of phyllite and mica schist were identified, with distinct foliation formed mainly by oriented aggregates of white mica and quartz (Fig. 8E, F). The undulose extinction of the monocrystalline quartz grains (Fig. 5A) and polycrystalline quartz aggregates with shape-preferred orientation of subgrains (Fig. 5C, D) are evidence for a source area where moderate grade metamorphic rocks were exposed to weathering. Finally, fragments of parallel laminated quartz siltstone, carbonate and chert document the presence of sedimentary rocks in the source area.

\section{COMPARISON OF PIWNICZNA AND POPRAD SANDSTONE MEMBERS}

Analysis of the these two sandstone members of the Magura Formation show the expected high similarity mainly in general features like the distinct dominance of thick structureless sandstone beds (almost 95\%; Figs. 3, 4 and 9). However, some differences were also recorded, allowing more precise interpretation of their depositional settings. Focusing on these differences, the sandstone profiles from the study area are defined as structureless, fine- to medium-grained (PwSM) and medium to coarse-grained (PpSM) sandstones interrupted by rhythmically thin-bedded sandstone-mudstone flysch (PwSM; Figs. 3, 5J and 9) and/or medium- to thick-bedded mudstones (PpSM; Figs. 4, 5K and 9). Mudstones are in some cases also dispersed within the sandstone beds as $\mathrm{mm}$-size clasts (PpSM; Fig. $5 \mathrm{C}$ ) or rarely as a deformed lenses or intercalations (PwSM; Fig. 3B). A distinct difference is also seen in the thickness of the continuous sandstone successions, lacking mudstone intercalations. In case of the PwSM such successions reach up to $12.3 \mathrm{~m}$ thick (profile 4, Fig. 3; $2 \mathrm{~m}$ in average), whilst those of the PpSM do not exceed 3,5 m thick (profile 1 , Fig. $4 ; 1 \mathrm{~m}$ in average).

Facies analysis show that the sedimentary successions studied were deposited mainly by high-density gravity flows. Most are preserved deposits of sandy debris flows $(73 \%$ in PpSM versus 63\% in PwSM; Fig. 9) and in lesser amounts those of high-density turbidity currents $(14 \%$ in PpSM versus
$26 \%$ in PwSM; Fig. 9). Deposits of a more muddy character are identified as low-density turbidites (5\% in PpSM versus $10 \%$ in PwSM; Fig. 9) and hemiturbidites (7\% in PpSM versus $1 \%$ PwSM; Fig. 9). Regarding the calculated percentages of the individual kinds of the gravity flows, it can be inferred that sedimentary deposition was relatively rapid and gradual transformation to more dilute flows was limited (PpSM), although in some profiles gradual transition from sandy debrites to high-density and/or to low-density turbidites can be seen (PwSM).

As regards the depositional environment, for both PpSM and PwSM depositional lobes and interlobe areas of a submarine fan are suggested. The difference comprises their position within these lobes. While the PpSM represents more proximal, lobe apex to axis positions, PwSM reflects lobe axis to off-axis, as well as lobe fringe to interlobe, positions (Fig. 6B). As a result, both of the sandstone types analysed are interpreted as lobe deposits of submarine fan, with the PwSM representing more distal positions than the PpSM.

The source area of the sandstones, located in the south-east in the the case of the studied deposits, as deduced from sole structures (see also Birkenmajer and Oszczypko, 1989; Oszczypko et al., 1990; Mišík et al., 1991), was most likely the same. This interpretation is supported by the results of thin-section analysis, which did not show any distinct differences between the sandstone successions compared. The sandstones are interpreted as subfeldspathic to feldspathic and lithic arenites. Only samples from profile 7 are characterized by a higher carbonate content than other samples, which may relate to their greater proximity to the source area. As evident from the QmFLt ternary provenance diagram (Fig. 9), the source area is interpreted as the mixed provenance of a suture area where tectonic collision occurred and petrographically variable tectonic units were uplifted. In case of the deposits studied, the South-Magura Ridge is proposed (Mišík et al., 1991; Oszczypko et al., 2006), representing the intensely tectonised zone formed as part of the accretionary prism rising between the Magura and PKB depositional areas.

On this basis, the PwSM and PpSM deposits are interpreted as a very similar, while there are some of differences between them, these are not fundamental. Therefore, it is very probable that the depositional history of these two sandstone members is closely linked and they represent the same depositional environment, i.e., the same submarine fan.

\section{CONCLUSIONS}

The deposits of the PpSM and PwSM are very similar in mineral composition as well as in sedimentary character. The analyses presented in the study show that they both were most likely supplied by the same source area and deposited as depositional lobes in close proximity to this source. This interpretation is supported by the immaturity of sandstones, their poor sorting, the low degree of rounding of the grains as well as by the content, although variable, of unstable plagioclases and carbonate grains. The modal composition of the sandstones analysed indicate a suture area characterized by petrographic heterogenity as a source area. This might be the South-Magura Ridge as a part of accretionary prism.

Despite their high similarity, facies analyses showed some differences between the sandstone successions. Among the most important, we note:

1. The clean sandstone successions of the PwSM are thicker, reaching 0.2 to $12.3 \mathrm{~m}$ ( $2 \mathrm{~m}$ on average), than the ones of the PpSM, reaching 0.1 to $3.5 \mathrm{~m}$ thickness (1 $\mathrm{m}$ on average). 

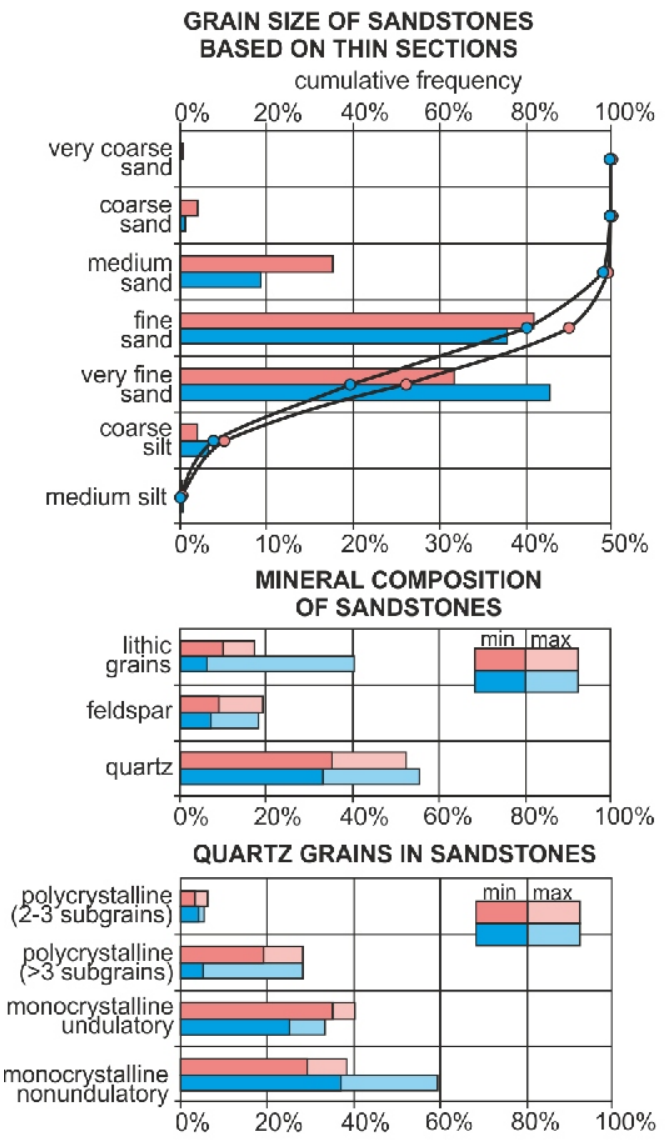

- $\square$ Poprad Sandstones

- $\square$ Piwniczna Sandstones

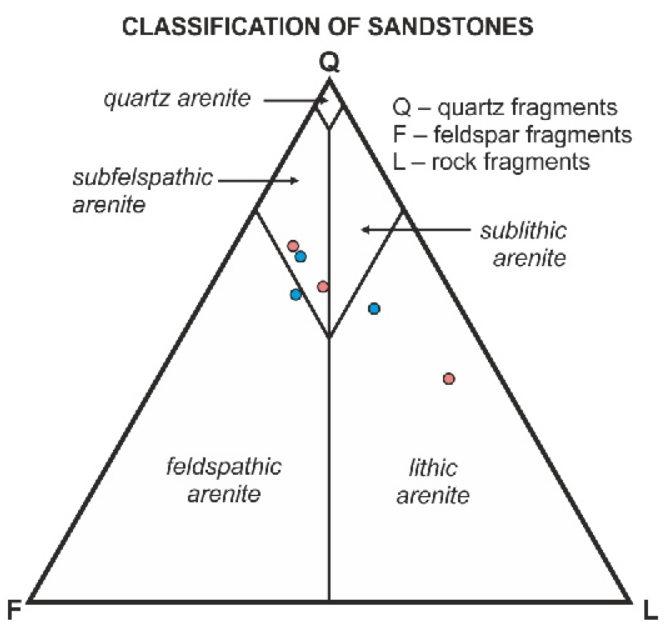

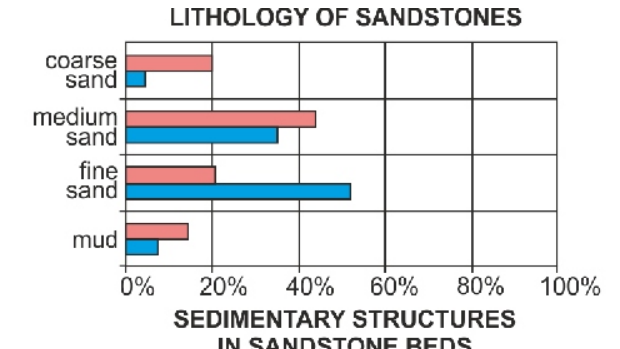

IN SANDSTONE BEDS

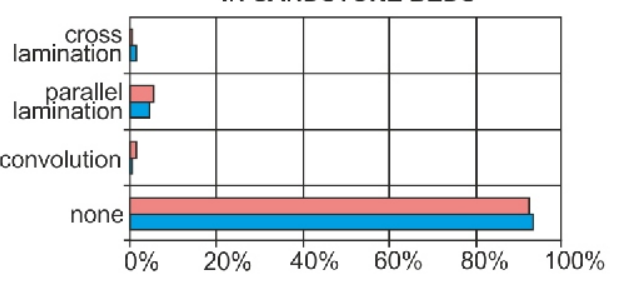

MUDSTONE CLASTS

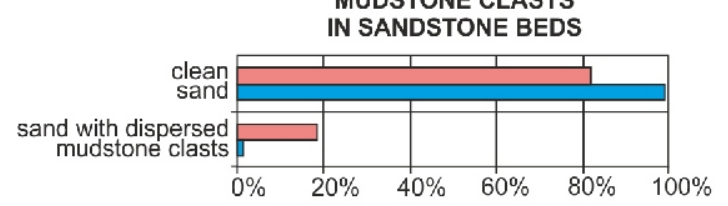

20\% $40 \% \quad 60 \% \quad 80 \% \quad 100 \%$

FINER INTERVALS BETWEEN

SANDSTONE SUCCESSIONS
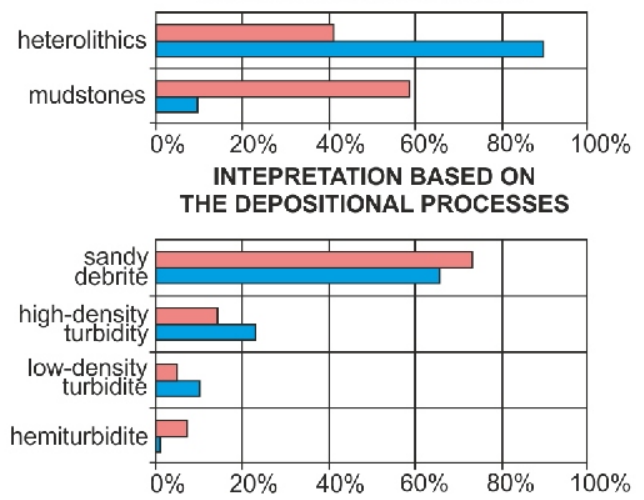

PROVENANCE OF SANDSTONES

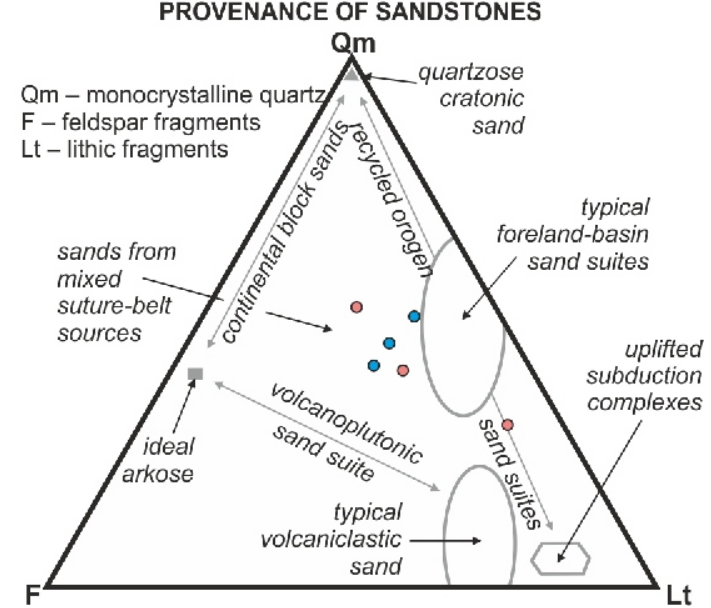

Fig. 9. Comparative graphs of some of the most important features and diagrams indicating type (based on Dott, 1964 ternary diagram modified by Pettijohn et al., 1972) as well as provenance (Dickinson, 1988) of the Poprad and Piwniczna Sandstone Member deposits 
2. The thick sandstones of the PpSM are coarser (medium- to coarse-grained) than those of the PwSM (fineto medium-grained).

3. Sandstone intervals are in the PwSM separated mostly by intervals of 0.2 to $3.6 \mathrm{~m}$ thick heterolithic deposits interpreted as a low-density turbidites. In the PpSM, on the other hand, there are intervals of mudstones interpreted as hemiturbidites 0.2 to $1 \mathrm{~m}$ in thickness.

4. The content of sandy debrites and high-density turbidites is lower in the PwSM (2.5:1) than in the PpSM (5:1).

5. The sandstone successions of the PwSM are interpreted as more distal parts of lobes (lobe axis to off-axis, lobe fringes, interlobe areas) than those of the PpSM (lobe apex to axis).
These differences are not fundamental. This is supported by the interpretation of depositional processes, i.e. gravity flows, forming the studied deposits, where the difference is in the proportion but not in the kind of these flows. Similarly, in both cases, the depositional lobes of a submarine fan are interpreted as the depositional environment, and the only difference is in the position within them.

Acknowledgements. The paper was written thanks to the support of the Operation Program Research and Development for Project 26220220031 co-financed from the resources of the European Foundation of Regional Development. Authors are grateful to L. Jankowski and anonymous reviewer for their suggestions and critical comments that were very helpful and significantly improved the manuscript.

\section{REFERENCES}

Arnott, R.W.C., Hand, B.M., 1989. Bedforms, primary structures and grain fabric in the presence of suspended sediment rain. Journal of Sedimentary Research, 59: 1062-1069.

Birkenmajer, K., 1977. Jurassic and Cretaceous lithostratigraphic units of the Pieniny Klippen Belt, Carpathians. Studia Geologica Polonica, 45: 1-159.

Birkenmajer, K., Oszczypko, N., 1989. Cretaceous and Palaeogene lithostratigraphic units of the Magura Nappe, Krynica Subunit, Carpathians. Annales Societatis Geologorum Poloniae, 59: 145-181.

Bónová, K., Spišiak, J., Bóna, J., Kováčik, M., 2017. Chromian spinels from the Magura Unit (Western Carpathians, Eastern Slovakia) - their petrogenetic and palaeogeographic implications. Geological Quarterly 61 (1): 3-17.

Bouma, A.H., 1962. Sedimentology of Some Flysch Deposits. A Graphic Approach to Facies Interpretation. Elsevier, Amsterdam.

Butler, R.W.H., Eggenhuisen, J.T., Haughton, P., McCaffrey, W.D., 2016. Interpreting syndepositional sediment remobilization and deformation beneath submarine gravity flows; a kinematic boundary layer approach. Journal of the Geological Society 173: 46-58.

Chrustek, M., Golonka, J., Janeczko, A. and Stachyrak, F., 2005. Geological characterisation of the Krynica Subunit in the vicinity of Krościenko on the Dunajec river (Magura Nappe, Outer Flysch Carapathians). Geologia, 31: 127-144.

Dickinson, W.R., 1970. Interpreting detrital modes of graywacke and arcose. Journal of Sedimentary Petrology, 40: 695-707.

Dickinson, W.R., 1985. Interpreting provenance relations from detrital modes of sandstones. In: Provenance of Arenites (ed. G.G. Zuffa): 333-336. Reidel, Dordrecht.

Dickinson, W.R., 1988. Provenance and sediment dispersal in relation to palaeotectonics and palaeogeography of sedimentary basins. In: New Perspectives in Basin Analysis (eds. K.L. Kleinspehn and C. Paola): 3-25. Springer-Verlag, New York.

Dickinson, W.R., Suczek, C.A., 1979. Plate tectonics and sandstone compositions. American Association of Petroleum Geologists Bulletin, 63: 2164-2182.

Dott, R.H., 1964. Wacke, greywacke and matrix; what approach to immature sandstone classification? Journal of Sedimentary Research, 34: 625-632.

Dżułyński, S., 1996. Erosional and deformational structures in single sedimentary beds: a genetic commentary. Annales Societatis Geologorum Poloniae, 66: 101-189.

Gazzi, P., 1966. Le arenarie del flyschsopracretaceo dell' Appennino modenese; correlazioni con il flysch di Mondghidoro. Mineralogica e Petrografica Acta, 12: 69-97.
Ghibaudo, G., 1992. Subaquaeous sediment gravity flow deposits: practical criteria for their field description and classification. Sedimentology, 39: 423-454.

Golonka, J., Gahagan, L., Krobicki, M., Marko, F., Oszczypko, N., Slaczka, A., 2006. Plate-tectonic evolution and paleogeography of the circum-Carpathian region. AAPG Memoir, 84: 11-46.

Hampton, M.A., 1972. The role of subaquaeous debris flows in generating turbidity currents. Journal of Sedimentary Petrology, 42 775-793.

Ingersoll, R.V., 1978. Petrofacies and petrologic evolution of the Late Cretaceous fore-arc basin, northern and central California. Journal of Geology, 86: 335-352.

Ingersoll, R.V., Suczek, C.A., 1979. Petrology and provenance of Neogene sand from Nicobar and Bengal fans, DSDP sites 211 and 218. Journal of Sedimentary Petrology, 49: 1217-1228.

Ingersoll, R.V., Bullard, T.F., Ford, R.L., Grimm, J.P., Pickle, J.D., Sares, S.W., 1984. The effect of grain size on detrital modes: a test of the Gazzi-Dickinson point-counting method. Journal of Sedimentary Petrology, 54: 0103-0116.

Kneller, B.C., Branney, M.J., 1995. Sustained high-density turbidity currents and the deposition of thick massive sands. Sedimentology, 42: 607-616.

Kováč, M., Sergeyeva-Grigorovich, A., Brzobohatý, R., Fodor, L., Harzhauser, M., Oszczypko, N., Pavelić, D., Rögl, F., Saftić, B., Sliva, L'., Stráník, Z., 2003. Karpatian paleogeography, tectonics and eustatic changes. In: The Karpatian a Lower Miocene Stage of the Central Paratethys (eds. R. Brzobohatý, I. Cicha, M. Kováč and F. Rögl): 49-72. Masaryk University, Brno.

Kováčik, M., Bóna, J., Gazdačko, L'., Kobulský, J., Maglay, J., Žecová, K., Derco, J., Zlinská, A., Siráňová, Z., Boorová, D., Bónová, K., Buček, S., Kucharič, L'., Kubeš, P., Bačová, N., Petro, L', Vaněková, H., 2012. Explanation to the geological map of the Nízke Beskydy Mts. - western part at 1:50,000 scale (in Slovak with English summary). State Geological Institute of Dionýz Štúr, Bratislava.

Ksiażkiewicz, M., 1960. Outline of the paleogeography in the Polish Carpathians (in Polish with English summary). Prace Instytutu Geologicznego, 30: 209-231.

Lamb, M.P., Myrow, P.M., Lukens, C., Houck, K., Strauss, J., 2008. Deposits from wave-influenced turbidity currents: Pennsylvanian Minturn Formation, Colorado, U.S.A. Journal of Sedimentary Research, 78: 480-498.

Lazar, O.R., Bohacs, K.M., Macquaker, J.H.S., Schieber, J., Demko, T.M., 2015. Capturing key attributes of fine-grained sedimentary rocks in outcrops, cores, and thin sections: nomen- 
clature and description guidelines. Journal of Sedimentary Research, 85: 230-246.

Lowe, D.R., 1979. Sediment gravity flows: their classification and some problems of application to natural flows and deposits. SEPM Special Publication, 27: 75-82.

Lowe, D.R., 1982. Sediment gravity flows: II, Depositional models with special reference to the deposits of high-density turbidity currents. Journal of Sedimentary Petrology, 52: 279-297.

Mišík, M., Sýkora, M., Jablonský, J., 1991. Strihov conglomerates and South Magura cordillera (in Slovak with English summary). Západné Karpaty, séria geológia, 14: 7-72.

Mulder, T., Alexander, A., 2001. The physical character of subaqueous sedimentary density flows and their deposits. Sedimentology, 48: 269-299.

Mulder, T., Syvitski, J.P.M., Migeon, S., Faugères, J.-C., Savoye, B., 2003. Marine hyperpycnal flows: initiations, behavior and related deposits. A review. Marine and Petroleum Geology, 20 861-882.

Mutti, E., 1987. Comparing examples of modern and ancient turbidite systems: problems and concepts. In: Marine Clastic Sedimentology (eds. J.K. Leggett and G.G. Zuffa): 1-38. Graham and Trotman, London.

Nemčok, J., 1990. Geologická mapa Pienin, Čergova, L'ubovnianskej a Ondavskej vrchoviny v mierke 1:50,000 (in Slovak) Geologický Ústav Dionýza Štúra, Bratislava.

Nemčok, J., Koráb, T., Ďurkovič, T., 1968. Lithological investigation of conglomerates of Magura flysch in east Slovakia Geologické práce, Správy: 44-45.

Nemčok, J., Zakovič, M., Gašpariková, V., Ďurkovič, T., Snopková, P., Vrána, K., Hanzel, V., 1990. Vysvetlivky ku geologickej mape Pienin, Čergova, L'ubovnianskej a Ondavske vrchoviny v mierke 1:50,000 (in Slovak). Geologický Ústav Dionýza Štúra, Bratislava.

Oszczypko, N. 1975. Exotic rocks in the Palaeogene of the Magura nappe between the Dunajec and Poprad Rivers (Carpathians, Poland) (in Polish with English summary). Rocznik Polskiego Towarzystwa Geologicznego, 45: 403-431.

Oszczypko, N., Oszczypko-Clowes, M., 2010. The Palaeogene and early Neogene stratigraphy of the Beskid Sądecki Range and Lubovnianska Vrchovina (Magura Nappe, Western Outer Carpathians). Acta Geologica Polonica, 60: 317-348.

Oszczypko, N., Salata, D., 2005. Provenance analyses of the Late Cretaceous-Palaeocene deposits of the Magura basin (Polish Western Carpathians) - evidence from a study of the heavy minerals. Acta Geologica Polonica, 55: 237-267.

Oszczypko, N., Zuchiewicz, W., 2007. Geology of Krynica Spa Western Outer Carpathians, Poland. Annales Societatis Geologorum Poloniae, 77: 69-92.

Oszczypko, N., Dudziak, J., Malata, E., 1990. Stratigraphy of the Cretaceous through Paleogene deposits of the Magura Nappe in Beskid Sądecki Range, Polish Carpathians (in Polish with English summary). Studia Geologica Polonica, 87: 109-181.

Oszczypko, N., Oszczypko-Clowes, M., Golonka, J., Marko, F., 2005. Oligocene-Lower Miocene sequences of the Pieniny
Klippen Belt and adjacent Magura Nappe between Jarabina and the Poprad River (East Slovakia and South Poland): their tectonic position and palaeographic implications. Geological Quarterly, 49 (4): 379-402.

Oszczypko, N., Oszczypko-Clowes, M., Salata, D., 2006. Exotic rocks of the Krynica Zone (Magura nappe) and their palaeogeographic significance. Geologia, 32: 21-45.

Pettijohn, F.J., Potter, P.E., Siever, R., 1972. Sand and Sandstones. New York, Springer-Verlag.

Pickering, K., Stow, D., Watson, M., Hiscott, R., 1986. Deep-water facies, processes and models: a review and classification scheme for modern and ancient sediments. Earth-Science Reviews, 23: 75-174.

Plašienka, D., 2003. Dynamics of Mesozoic pre-orogenic rifting in the Western Carpathians. Mitteilungen der Österreichischen Geologischen Gesellschaft, 94: 79-98.

Plašienka, D., Mikuš, V., 2010. Geologická stavba pieninského a šarišského úseku bradlového pásma medzi Litmanovou a Drienicou na východnom Slovensku (in Slovak). Mineralia Slovaca, 42: 155-178.

Prèlat, A., Hodgson, D.M., Flint, S.S., 2009. Evolution, architecture and hierarchy of distributary deep-water deposits: a high-resolution outcrop investigation from the Permian Karoo Basin, South Africa. Sedimentology, 56: 2132-2154.

Salata, D., Oszczypko, N., 2010. Preliminary results of provenance analyses of exotic magmatic and metamorphic rock pebbles from the eocene flysch deposits of the magura nappe (Krynica facies zone, Polish outer Carpathians). Proceedings of the XIX CBGA Congress, Thessaloniki, Greece, Special volume, 100: 241-248.

Shanmugam, G., 2013. New perspectives on deep-water sandstones: implications. Petroleum Exploration and Development 40: 316-324.

Spychala, Y.T., Hodgson, D.M., Prèlat, A., Kane, I.A., Flint, S.S., Mountney, N.P., 2017. Frontal and lateral submarine lobe fringes: comparing sedimentary facies, architecture and flow processes. Journal of Sedimentary Research, 87: 75-96.

Stow, D.A.V., Wetzel, A., 1990. Hemiturbidite: a new type of deep-water sediment. Proceedings of the Ocean Drilling Program, Scientific Results, 116: 25-34.

Talling, P.J., Masson, D.G., Sumner, E.J., Malgesini, G., 2012 Subaqueous sediment density flows: depositional processes and deposit types. Sedimentology, 59: 1937-2003.

Walker, R.G., 1976. Facies Models 2. Turbidites and Associated Coarse Clastic Deposits. Geoscience Canada, 3: 25-36.

Žec, B., Gazdačko, L'., Kováčik, M., Kobulský, J., Bóna, J., Potfaj, M., Pristaš, J., Žecová, K., Derco, J., Kucharič, L'. Marcin, D., Petro, L'., Zlinská, A., Siráňová, Z., Vaněková, H., Buček, S., Konečný, P., 2011. Explanations to Geological map of the Nízke Beskydy Mts. - central part $(1: 50,000)$ (in Slovak with English summary). Publ. Ministry of the Environment of the Slovak Republic and State Geological Institute of Dionýz Štúr, Bratislava. 